\title{
Konsep Sunnah dalam Pembelajaran Sains
}

\author{
Zubaidah Amir MZ1, Risnawati², Ramon Muhandaz ${ }^{3}$ \\ Universitas Islam Negeri Sultan Syarif Kasim Riau, Indonesia \\ e-mail: \\ 1zubaidah.amir@uin-suska.ac.id \\ 2rwati04@gmail.com \\ 3ramon.muhan@uin-suska.ac.id
}

\begin{abstract}
.
This article discusses the concept of teaching mathematics and the concept of sunnah. The purpose of writing this article is to discuss how the concept of teaching that is shown Rasulullah S.A.W. through its sunnah which is integrated into the teaching. The method of writing used in the preparation of this article is the literature study method. Some of the teaching concepts shown by Rasulullaab S.A.W. through sunnahnya and can be used as a guide in forming the concept of teaching, among others: (1) explore apersepsi through question and answer, it aims to remind the learners of the previous lesson material to then proceed to the next material; (2) teach with wisdom, good lessons, and argue in a good way. One of the lessons of wisdom when a teacher teaches the right target, prioritizes crucial material, taught by understanding the situation, condition, and ability of the learner, and conveying instruction in an easily understood language. A good lesson is meant for each subject to be taught to contain the advice and useful values applicable to the learner's life. While arguing in a good way means that in straightening the misconception of mathematics that occurs in the students gun must convey it in a good way; (3) Using learning media while teaching aimed at assisting teachers in facilitating students to understand the concept given by the teacher. Some of the teaching mediums chosen by Rasulullaab S.A.W when teaching the Companions are drawings, fingers, and bones; and (4) applying the material and values of characters in life, such as fair, honest, systematic, and so on.
\end{abstract}

Keywords: Learning with Sunnah, Learning Media, Wisdom, Islamic Character Values

\begin{abstract}
ABSTRAK.
Artikel ini membahas konsep mengajar matematika dan konsep sunnah. Tujuan penulisan artikel ini adalah untuk membahas bagaimana konsep pengajaran yang ditunjukkan Rasulullah S.A.W. melalui sunnahnya yang terintegrasi ke dalam pengajaran. Metode penulisan yang digunakan dalam penyusunan artikel ini adalah metode studi pustaka. Beberapa konsep mengajar yang ditunjukkan oleh Rasulullaah S.A.W. melalui sunnahnya dan dapat digunakan sebagai panduan dalam membentuk konsep mengajar, antara lain: (1) mengeksplorasi apersepsi melalui tanya jawab, ini bertujuan untuk mengingatkan peserta didik dari materi pelajaran sebelumnya untuk kemudian melanjutkan ke materi berikutnya; (2) ajarkan dengan kebijaksanaan, pelajaran yang baik, dan berdebat dengan cara yang baik. Salah satu pelajaran dari kebijaksanaan ketika seorang guru mengajarkan target yang tepat, memprioritaskan materi penting, diajarkan dengan memahami situasi, kondisi, dan kemampuan pelajar, dan menyampaikan instruksi dalam bahasa yang mudah dipahami. Pelajaran yang baik dimaksudkan untuk setiap mata pelajaran yang diajarkan untuk berisi nasihat dan nilai-nilai berguna yang berlaku untuk kehidupan pembelajar. Sementara berdebat dengan cara yang baik berarti bahwa dalam meluruskan kesalahpahaman matematika yang terjadi pada siswa guu harus menyampaikannya dengan cara yang baik; (3) Menggunakan media pembelajaran sambil mengajar yang bertujuan membantu guru dalam memfasilitasi siswa untuk memahami konsep yang diberikan oleh guru. Beberapa medium pengajaran yang dipilih oleh Rasulullaah S.A.W ketika mengajar para Sahabat adalah gambar, jari, dan tulang; dan (4) menerapkan materi dan nilai-nilai karakter dalam kehidupan, seperti adil, jujur, sistematis, dan sebagainya.
\end{abstract}


Kata Kunci: Pembelajaran dengan Sunnah, Media Pembelajaran, Hikmah, Nilai Karakter Islami

\section{PENDAHULUAN}

Guru memainkan peranan penting terhadap proses dan keberhasilan peserta didik dalam belajar. Hal ini didukung oleh Salleh bahwa faktor guru signifikan dalam mempengaruhi minat dan komitmen peserta didik terhadap pelajaran serta berpotensi mengubah sikap dan status peserta didik terhadap suatu kurikulum (dalam Arbaa dkk, 2010). Diungkapkan oleh Purwanto (dalam Syarifuddin, 2011) bahwa faktor-faktor yang mempengaruhi belajar seseorang dibedakan menjadi dua golongan, yaitu Faktor individual, yaitu faktor yang ada pada diri organisme itu sendiri, kematangan atau pertumbuhan, kecerdasan, latihan, motivasi, dan faktor pribadi; Faktor sosial, yaitu faktor yang ada di luar individu, keluarga (rumah tangga), guru dan cara mengajarnya, alat-alat yang dipergunakan dalam belajar mengajar, lingkungan dan kesempatan yang tersedia dan motivasi sosial. Implikasinya terhadap proses pembelajaran, termasuk pembelajaran adalah seharusnya guru harus merancang pembelajaran dengan baik sehingga pembelajaran menjadi bermakna bagi siswa dan dapat membangun pemahaman konsep peserta didik terhadap.

Dewasa ini berbagai inovasi mulai bermunculan dicetuskan oleh para ahlinya di bidang pendidikan. Inovasi-inovasi tersebut dapat berbentuk strategi-strategi pembelajaran, metode mengajar, media pembelajaran, dan lain-lain yang secara keseluruhan diciptakan dan dikembangkan demi tercapainya tujuan pembelajaran dan pendidikan. Padahal, jauh sebelum para ahli mematenkan temuan pendidikan, Al-Qur'an dan sunnah telah terlebih dahulu memberikan konten pendidikan bagi umat manusia. Rasulullaah S.A.W. Sebagai utusan Allah S.W.T. mempertegas urgensi Al-Qur'an dan sunnah sebagai panduan manusia dalam segala aspek kehidupan melalui sabdanya yang diriwayatkan oleh Malik (dalam Idris dan Mahyuni, 2013), yaitu: "Dari Anas bin Malik bersabda Rasulullah SAW: Aku tinggalkan dua pusaka untukmu sekalian, yang kalian tidak akan tersesat selagi kamu berpegang teguh pada keduanya, yaitu berupa kitab Allah dan sunah rasul-Nya”. (H.R. Malik). Hadist ini idealnya menjadi dasar bagi guru untuk mengemas konsep pembelajaran yang berlandaskan pada Al-Qur'an dan sunnah, karena adalah bagian dari pendidikan dan pendidikan bagian dari kehidupan manusia.

Rasulullaah S.A.W. ketika mengajarkan para sahabat, beliau menggunakan konsep yang sangat apik. Keberhasilan Rasulullaah S.A.W. dalam mengajarkan pendidikan kepada para sahabat patut dijadikan contoh bagi guru agar tercapainya tujuan pembelajaran. Allah S.W.T. telah mengukuhkan bahwa Rasulullaah S.A.W. adalah suri teladan umat dalam surah Al-Ahzab ayat 31 (dalam Marzuki, 2008) yang memiliki arti: "Sesungguhnya telah ada pada (diri) Rasulullah itu suri teladan yang baik bagimu (yaitu) bagi orang yang mengharap (rahmat) Allab dan (kedatangan) hari kiamat dan dia banyak menyebut Allah".

Berdasarkan latar belakang yang telah dipaparkan, yang menjadi rumusan masalahnya adalah bagaimana konsep sunnah dalam pembelajaran yang telah ditunjukkan Rasulullaah S.A.W. dan integrasinya terhadap pembelajaran. Adapun tujuan penulisan artikel ini adalah untuk mendeskripsikan konsep sunnah yang ditunjukkan Rasulullaah S.A.W. dalam pembelajaran sebagai suri teladan manusia dan mengaitkan konsep sunnah kepada pembelajaran . 


\section{METODOLOGI}

Metode yang dilakukan penulis adalah studi pustaka. Studi literatur adalah cara yang dipakai untuk menghimpun data-data atau sumber-sumber yang berhubungan dengan topik yang diangkat dalam suatu penelitian. Studi literatur bisa didapat dari berbagai sumber, jurnal, buku dokumentasi, internet dan pustaka.

\section{TEMUAN DAN PEMBAHASAN}

\section{Pembelajaran dan Konsep Sunnah}

Pada dasarnya konsep mengajar diturunkan dari konsep pembelajaran secara umum. Konsep pembelajaran yang ditunjukkan Rasulullaah S.A.W. melalui sunnahnya adalah salah satu yang dapat dijadikan guru sebagai pedoman, khususnya pada materi pelajaran yang membutuhkan kreativitas dan juga kesiapan mental dari guru untuk mendudukkan konsep dasar materi. Pada pembahasan ini akan dikaji cara-cara Rasulullaah S.A.W. dalam memberikan pembelajaran yang selanjutnya akan dikaitkan dengan pembelajaran terhadap materi .

\section{Menggali Apersepsi melalui Tanya-jawab.}

Pada tahap persiapan guru berusaha mengungkapkan kembali apersepsi peserta didik, yaitu materi pelajaran yang tersimpan di dalam ingatan. Dalam Kamus Besar Bahasa Indonesia (dalam R. Mansur, 2015) dikatakan bahwa apersepsi adalah pengamatan secara sadar tentang segala sesuatu yang ada pada diri sendiri yang menjadi dasar perbandingan serta landasan untuk menerima ide baru. Dapat pula dikatakan bahwa apersepsi adalah memperoleh tanggapan-tanggapan baru dengan bantuan tanggapan yang telah ada ( $R$. Mansur, 2015) dengan mengajukan sejumlah pertanyaan kepada peserta didik atau mengajukan suatu masalah Baroroh (2004). Berdasarkan pemaparan para ahli dapat disimpulkan bahwa apersepsi adalah kegiatan memanggil ide-ide yang telah ada untuk dijadikan dasar dalam menerima ide baru.

Yusuf (dalam Basrudin et al., 2013) memberikan pandangannya bahwa metode tanya-jawab merupakan suatu cara untuk menyampaikan atau menyajikan bahan pelajaran dalam bentuk pertanyaan dari guru yang harus dijawab oleh peserta didik dan sebaliknya, dapat merangsang peserta didik untuk berpikir kritis, mendorong peserta didik berusaha memahami setiap pertanyaan yang diberikan oleh guru (2013). Melalui tanya-jawab memungkinkan terciptanya aktivitas proses mental peserta didik untuk melihat adanya hubungan yang tersedia dalam materi pembelajaran.

Tanya-jawab dalam upaya membangun apersepsi telah diperlihatkan dalam kisah malaikat Jibril A.S. yang menemui Rasulullah S.A.W ketika sedang berkumpul dengan sahabat-sahabatnya dan kemudian mengajukan beberapa pertanyaan. Kisah ini diriwayatkan dalam hadist riwayat Muslim (dalam Salafudin, 2011) yang artinya "Ketika sedang dudukduduk dengan Rasulullaab S.A.W., tiba-tiba datang seseorang dengan pakaian putih bersih, penampilannya sangat rapi, tak satu pun dari kami yang mengenalnya. Dia segera mengambil posisi dengan duduk sopan berhadapan langsung dengan Rasulullaah S.A.W. Lalu dia membuka percakapan. "Mubammad, beri tabu aku tentang Islam." ... "Sekarang beri tabu aku tentang iman", ... "Beri tahu aku juga tentang ibsan", tanya orang itu lagi. ... "Kalau hari kiamat?". ... "Dia adalab Jibril, dia datang kepada kalian untuk mengajarkan pada kalian tentang (inti) agama yang kalian peluk." (H.R. Muslim).

Dari hadits tentang dialog antara malaikat Jibril dan Nabi Muhammad S.A.W., dapat dipetik pelajaran sebagai berikut: (1) Jibril datang kepada Nabi Muhammad dan para sahabat untuk mengajarkan ilmu dengan penampilan yang bersih dan sangat rapi. Seyogyanya sebagai seorang pendidik guru harus berpenampilan sebaik mungkin untuk 
menimbulkan kesan yang baik pula terhadap peserta didik.(2) Jibril berdialog dan mengajukan beberapa pertanyaan kepada Rasulullaah S.A.W. dan ketika Rasulullaah benar menjawabnya, beliau membenarkan. Hal ini mengindikasikan bahwa Jibril mengajukan pertanyaan yang mendorong Rasul dan para sahabat untuk berpikir, kemudian Rasul menjawab sesuai dengan apa yang telah beliau pelajari dan ketahui. Para sahabat yang menyimak menjadi tahu tentang konsep Islam, Iman, Ihsan, dan hari Kiamat.

Dalam pembelajaran, jika guru langsung menyampaikan materi secara langsung, maka peserta didik cenderung hanya akan menghapal dan hapalan tersebut tidak akan bertahan lama dan konsep tidak tersampaikan dengan baik. Oleh karena itu perlu membangun terlebih dahulu apersepsi peserta didik, mengarahkan kembali peserta didik sehingga ide-ide dan pengalaman yang pernah terjadi pada diri mereka muncul melalui tanya-jawab. Misalnya, guru dapat mengajukan pertanyaan-pertanyaan terkait himpunan, seperti: Apakah peserta didik tahu tentang Kalender Hijriyah? Dalam 1 tahun Hijriyah terdapat berapa bulan? Apa saja nama-nama bulan dalam kalender Hijriyah? Bisa tidak bulan-bulan dalam kalender Hijriyah kita kelompokkan berdasarkan jumlah hari? Bulan apa saja ya yang harinya berjumlah 28? Dan bulan apa saja yang jumlah harinya 29?

Mengajukan pertanyaan-pertanyaan terkait himpunan membuat ide-ide peserta didik akan muncul kembali. Akibatnya peserta didik akan mengingat konsep ruang sampel untuk jangka waktu yang sangat lama dan jika peserta didik diberitahu definisi ruang sampel, titik sampel, dan kejadian, maka tidak sulit lagi bagi mereka memahami apa yang diajarkan kepadanya karena mereka telah memiliki pengalaman terkait materi ruang sampel.

Mengajar dengan hikmah, pelajaran yang baik, dan membantah dengan cara yang baik

Allah S.W.T berfirman dalam surah An-Nahl ayat 125 (el-Qurtuby, 2012), yaitu:

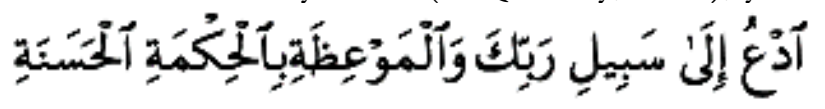

Artinya: "Serulah (manusia) kepada jalan Tuhan-mu dengan bikmah dan pelajaran yang baik dan bantablah mereka dengan cara yang baik." Ayat tersebut bila dikaitkan dengan konsep pembelajaran, maka dapat ditarik kesimpulan bahwa dalam mengajar guru harus mengajar dengan hikmah, memberikan pelajaran yang baik, dan memberikan bantahan atau meluruskan miskonsepsi yang terjadi pada peserta didik dengan cara yang baik pula.

Hikmah berarti tepat sasaran, yakni dengan meletakkan sesuatu sesuai pada tempatnya (Ramli, 2015). Begitu pula ketika guru mengajarkan, termasuk bagian dari hikmah saat guru menyampaikan materi sesuai ilmu yang dimilikinya, mendahulukan bagian-bagian terpenting, memperhatikan bagaimana situasi dan kondisi peserta didik, memahami kemampuan peserta didik dalam menerima pelajaran, mengajar dengan menggunakan bahasa yang mudah dipahami serta bertutur kata yang halus. Pelajaran yang baik dimaksudkan sebagai nasihat yang baik dan perkataan yang menyentuh (Ramli, 2015). Dalam pembelajaran hal ini dapat dimaknai bahwa materi yang telah diajarkan guru kepada peserta didik memiliki manfaat dan nilai guna dalam kehidupan.

Bantahlah mereka dengan cara yang baik yang dimaksud adalah jika peserta didik salah dalam memahami konsep dan bersikeras dengan pendapatnya, maka sebagai seorang guru haruslah meluruskan pemahaman tersebut dengan membantah menggunakan cara yang baik, yakni cara yang dapat membuat peserta didik mau mengikuti apa yang guru ajarkan. Salah satu cara yang baik itu adalah dengan menggunakan dalil atau bukti yang kuat, kemudian disampaikan dengan cara yang halus, tidak menjatuhkan mental peserta didik, dan jangan sampai membuatnya malu. Bantahan tersebut dilakukan untuk 
mengembalikan peserta didik kepada pemahaman konsep yang benar, bukan untuk mengalahkannya.

Implementasinya dalam pembelajaran, misalnya ketika seorang peserta didik mengerjakan soal di papan tulis dan hasilnya salah, guru jangan langsung mengatakan bahwa hasil pekerjaannya salah, jangan mengatakan kepada peserta didik bahwa ia bodoh karena perkataan demikian dapat menjatuhkan mental seseorang. Cara yang lebih baik yang dapat dilakukan oleh guru untuk memperbaiki kesalahan peserta didik, misalnya dengan memberi penguatan seperti: Hasil pekerjaan kamu sudah bagus, Nak. Hanya saja perlu diperbaiki sedikit lagi pada bagian ...., Jawaban yang kamu tuliskan hampir benar, tetapi ada sedikit yang kurang, coba kamu perhatikan lagi di bagian ..... Sepertinya si A mengalami sedikit kendala, adakah di sini yang ingin membantu temannya mengerjakan soal di depan?

Ada begitu banyak cara lainnya yang dapat dilakukan guru untuk memperbaiki kesalahan peserta didikdan secara keseluruhan ilmu yang diajarkan kepada peserta didik jangan membuat mereka merasa semakin susah dan pada akhirnya menjauhkan diri. Rasulullaah S.A.W. sebagai sosok guru teladan umat bersabda dalam hadits riwayat Tirmidzi (dalam Salleh dan Abdullah, 2014): "Sesunggubnya Allah S.W.T. mengutus aku untuk menyampaikan ajaran bukan untuk menyusabkan", dan dipertegas oleh sabda beliau yang diriwayatkan Bukhari (dalam Salleh dan Abdullah, 2014): "Hendaklah kamu mempermudabkan dan jangan mempersulitkan, ajaklah dengan baik. (gembirakanlab) dan jangan kamu jadikan mereka menjaubkan dir"'.

\section{Menggunakan media pembelajaran}

Dalam rangka mendudukkan konsep seorang guru dapat menggunakan media dalam mengajar. Hal ini bertujuan agar peserta didik dapat belajar dari sesuatu yang konkret sebelum diberikan sesuatu yang abstrak. Rasulullaah S.A.W pun menerapkan cara ini, walaupun media yang digunakan tidaklah secanggih teknologi yang ada pada saat ini. Beberapa media yang digunakan Rasulullah S.A.W. yang dapat kita jadikan sebagai contoh ketika mengajarkan kepada peserta didik adalah sebagai berikut. Pertama, menggunakan media gambar. Dalam sebuah hadits yang diriwayatkan Jabir dan Ibnu Abbas (dalam Hussin, 2013), dikatakan bahwa: Dari Abdullah bin Abbas, katanya bahwa Rasulullah S.A.W. membuat empat garis di atas tanah seraya bersabda: "adakah kamu tahu mengapa aku melakarkan empat garis ini?". Mereka menjawab, "Allah dan rasul-Nya lebih mengetahui". Lalu Rasulullah S.A.W. bersabda: "Semulia-mulia wanita di dalam surga ada empat orang yaitu Khadijah binti Khuwailid, Fatimah binti Mubammad, Maryam binti Imran dan Asiab binti Murabin istri Fir'aun".

Rasulullaah S.A.W. pernah menjelaskan tentang gambaran kehidupan manusia menggunakan gambar persegi dan garis sebagaimana yang dikatakan dalam hadits riwayat Bukhori (dalam Ramli, 2015) berikut yang artinya: "Telah menceritakan kepada kami Sodaqoh bin Fadhil, telah memberikan kabar kepadaku Yabya bin Sa'id dari Sofyan, Beliau bersabda: Telah menceritakan kepadaku bapakeku dari Mundzir dari Robi' bin Khusein dan Abdullah R.A, Beliau bersabda: Nabi S.A.W. pernah membuat garis (gambar) persegi empat dan membuat suatu garis lagi di tengah-tengah sampai keluar dari batas (persegi empat), kemudian beliau membuat banyak garis kecil yang mengarah ke garis tengah dari sisi-sisi garis tepi, lalu beliau bersabda: Beginilah gambaran manusia. Garis persegi empat ini adalah ajal yang pasti bakal menimpanya, sedang garis yang keluar ini adalah angan-angannya, dan garis-garis kecil ini adalah berbagai cobaan dan musibah yang siap menghadangnya. Jika ia terbebas dari cobaan yang satu, pasti akan tertimpa cobaan lainnya, jika ia terbebas dari cobaan yang satunya lagi, pasti akan tertimpa cobaan lainnya lag?'(HR. Imam Bukhori). 


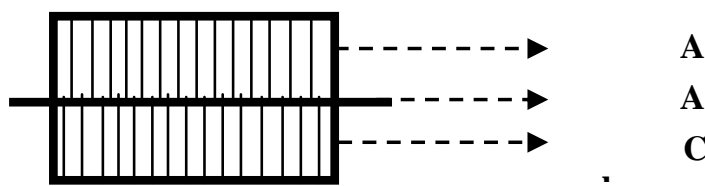

Gambar 1. Estimasi gambar buatan Rasulullaah S.A.W.

Rasulullaah S.A.W. mengumpamakan keliling persegi sebagai ajal yang pasti akan menimpa manusia, sedangkan garis tengah yang keluar dari persegi adalah angan-angan panjang manusia, dan garis-garis dari tepi persegi menuju garis tengah digambarkan sebagai cobaan dan musibah yang selalu menghadang manusia. Jadi, tampaklah dari hadits bahwa gambar menjadi media yang dapat membantu guru mengilustrasikan sesuatu, seperti Rasulullaah S.A.W. yang mengilustrasikan kehidupan manusia melalui gambar persegi empat.

Media berbentuk gambar dalam pembelajaran misalnya pada materi Fungsi Komposisi. Menanamkan konsep awal tentang fungsi komposisi dapat dilakukan oleh guru dengan menggunakan gambar yang memperlihatkan sebuah proses, seperti gambar tentang proses pembuatan nasi dari padi. Untuk menjadi nasi yang matang padi harus melalui tahap-tahap atau operasi secara berurutan. Tahapan-tahapan tersebut adalah: pertama, padi diproses pada mesin yang dirancang untuk fungsi memisahkan padi dengan kulitnya sehingga diperoleh beras; dan kedua, beras dimasukkan ke dalam mesin (magic com) yang dirancang untuk menjalankan fungsi menanak beras sehingga didapatlah nasi yang matang dan siap untuk dimakan seperti gambar di bawah.

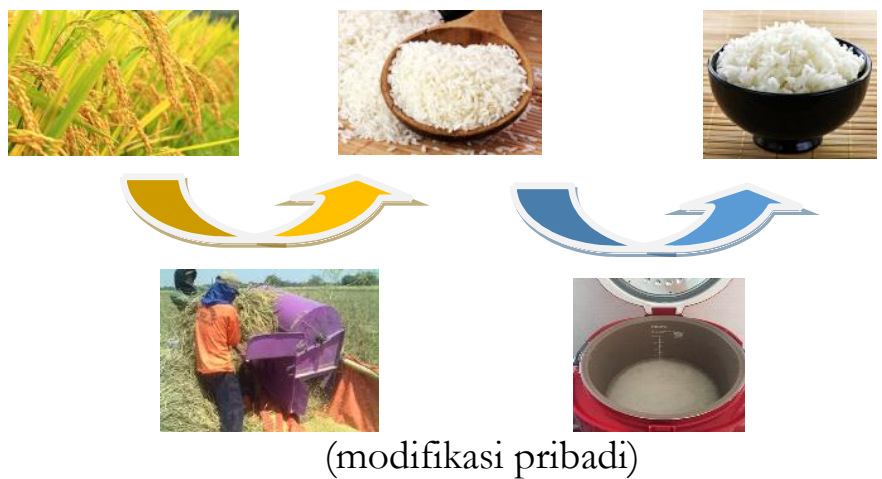

Gambar 2. Diagram alir padi - beras - nasi

Kedua, menggunakan media Jari tangan. Suatu ketika Rasulullaah S.A.W. menyabdakan tentang betapa istimewanya memiliki anak perempuan dan Rasulullaah menggunakan jemarinya untuk mempertegas keistimewaan tersebut. Kejadian itu diriwayatkan dalam hadist berikut. Artinya: "Telah menceritakan padaku Amrun dan Naqid. Telab menceritakan pada kami Abu Ahmad Zubair. Telah menceritakan pada kami Mubammad bin Abdul Aqiq, dari Ubaidillah bin Abu Bakar bin Anas, dari Anas bin Malik r.a: Rasulullab SAW bersabda, "Barang siapa memelibara dua anak perempuan sampai baligh, maka pada hari kiamat dia datang bersamaku," beliau menggenggam jemarinya." (HR. Imam Muslim)

Rasulullaah S.A.W. menggenggam jemarinya untuk memberikan penegasan dan agar mudah dipahami bahwa jika orang yang memelihara dua anak perempuannya hingga ia dewasa atau sudah menikah, maka di hari kiamat nanti orang itu akan dekat dengan Rasulullaah S.A.W (Ramli, 2015). Dari hadits yang menunjukkan bahwa Rasulullaah S.A.W. 
menggunakan jari-jemari sebagai media pembelajaran, terlihat bahwa selain untuk membantu mempermudah dalam penyampaian materi, media juga dapat digunakan untuk menekankan atau mempertegas suatu hal.

Penggunaan jari-jemari pada materi pelajaran yang erat hubungannya dengan hitungmenghitung sudah pasti banyak dirasakan manfaatnya oleh peserta didik. Teknik menghitung menggunakan jemari yang paling populer diketahui saat ini adalah Jarimatika. Wulandani (dalam Elita, 2012) menyatakan bahwa jarimatika adalah salah satu metode berhitung (operasi Kali-Bagi-Tambah-Kurang) dengan menggunakan jari-jari tangan. Contoh penggunaan jari tangan untuk operasi perhitungan pada memperlihatkan bahwa pemilihan media memperhatikan nilai tepat guna dalam penggunaannya pada proses pembelajaran. Jadi, sesederhana apa pun media yang digunakan, seperti jari-jemari dan lainlain, selama memiliki daya guna maka media tersebut boleh digunakan dalam pembelajaran.

Ketiga, menggunakan media kerikil. Dalam menggunakan media pembelajaran, seorang guru hendaknya mampu memanfaatkan benda-benda alam yang ada, seperti halnya yang dilakukan Rasulullaah S.A.W. Beliau memilih media dengan mempertimbangkan nilai tepat guna dalam pemakaiannya, benda paling sederhana seperti kerikil pun dapat menjadi media pembelajaran oleh Rasulullaah S.A.W. Berikut hadist riwayat Tirmidzi (dalam Ramli, 2015) yang mengungkapkan penggunaan krikil sebagai media yang dipilih Rasulullaah S.A.W. untuk menjelaskan tentang ajal dan angan manusia. Artinya: "Telah menceritakan kepada kami Mubammad bin Isma'il, dan telah memberi kabar kepada kami Khollad bin Yabya, telah menceritakan kepada kami Basyir ibn al-Mubajir, telah memberi kabar kepadaku Abdullah bin Buraidah dari Ayahnya, beliau berkata: "Rasulullah S.A.W bertanya kepada para sababat, Tahukah kalian semua, apakah sesuatu ini? Rasulullah SAW sambil melemparkan dua krikil, para shahabat menjawab, Allah dan Rasul-Nya lab yang lebih tabu, kemudian Rasulullah SAW bersabda Sesuatu ini adalah angan-angan dan ini adalah ajal". Abu 'Isa berkata: Ini hadits hasan yang nampak asing" (H.R. At-Tirmidzi).

Dari hadits di atas dapat diketahui bahwa Rasulullaah S.A.W. menggunakan krikil sebagai media pembelajaran untuk mengingatkan manusia bahwa kehidupan tidak hanya sekali saja, ada ajal yang menjadi perantara masuk ke kehidupan berikutnya. Beberapa penggunaan media yang dicontohkan Rasulullaah S.A.W. dalam mengajarkan sesuatu, dapat ditarik kesimpulan bahwa guru harus memilih media yang komunikatif dan variatif, dan menggunakan media yang ada disekitar agar memudahkan peserta didik dalam memahami materi yang disajikan.

\section{Mengaplikasikan Materi dan Nilai Karakter dalam Kehidupan}

Seorang pendidik hendaknya menyampaikan sesuatu yang sesuai dengan apa yang ia kerjakan, jangan sampai berbeda antara tutur kata dan perbuatannya. Dalam A-Qur'an surah Al-Baqarah ayat 44 (dalam Aslamiyah, 2013) dikatakan bahwa: "Apakah engkan menganjurkan orang lain berbuat baik, sedang engkau sendiri melupakan dirimu?". Menyampaikan sesuatu yang tidak kita lakukan kepada orang adalah salah satu dosa besar, sebagaimana yang telah Allah S.W.T tegaskan dalam surah Shaf ayat 3 (dalam Aslamiyah, 2013): "Tergolong dosa besar di sisi Allah engkau mengucapkan apa yang tidak engkau lakukan".

Begitu pula dengan ilmu, baik yang disampaikan oleh guru sebagai pengajar maupun yang diterima oleh peserta didik, harus diimplementasikan dalam kehidupan sehari-hari. Ilmu yang diaplikasikan dalam kehidupan tidak terbatas hanya pada materi saja, tetapi juga nilai-nilai karakter yang terkandung di dalamnya. Mengaplikasikan materi pembelajaran di dalam kehidupan, misalnya setelah belajar aritmatika sosial menjadikan seseorang lebih cermat dan teliti mengatur keuangan agar tidak terjerumus ke dalam sifat boros dan menjadi pribadi yang lebih jujur dalam berdagang. 
Rasulullaah S.A.W. bersabda sebagaimana diriwayatkan oleh Bukhari dan Muslim (dalam Dahlan, 2014): "Dari Ibnu Mas'ud ra., dari Nabi saw., bersabda sesunggubnya kebenaran itu membawa kepada kebaikan dan kebaikan itu membawa surga. Seseorang akan selalu bertindak jujur sehingga ia ditulis di sisi Allah sebagai orang yang jujur. Dan sesunggubnya dusta itu membawa kepada kejahatan dan kejahatan itu membawa ke neraka. Seseorang selalu berdusta sebingga ia ditulis di sisi Allah sebagai pendusta" (HR. Bukhari-Muslim). juga mengajarkan keadilan, misalnya untuk memperoleh penyelesaian dari sistem persamaan linier, kedua ruas (kiri dan kanan) harus sama-sama dibagi atau dikurangi. Pada materi fungsi komposisi, guru dan peserta didik belajar bahwa untuk memperoleh sesuatu harus terlebih dahulu melalui proses yang teratur (sistematis).

Menurut Supinah dan Parmi (dalam Maharani, 2014) pembelajaran yang dapat membentuk peserta didik memiliki nilai budaya dan karakter bangsa sebagai berikut: Karakter utama untuk pelajaran meliputi berpikir logis, kritis, kerja keras, keingintahuan, kemandirian, percaya diri; Karakter pokok meliputi religius, jujur, cerdas, tangguh, peduli, dan demokratis.

Beberapa contoh penerapan nilai karakter dalam pembelajaran adalah sebagai berikut (Bilda, 2016): Peserta didik secara berkelompok diberi tugas untuk menghitung luas ruang kelas dan lapangan upacara secara detail dalam satuan meter. Guru terlebih dahulu telah mengetahui ukuran luas keduanya. Peserta didik yang malas, akan berlaku curang dengan berpura-pura telah menghitungnya. Kemudian hasil pengukuran, didiskusikan dengan kelompok lainnya di bawah bimbingan guru. Disinilah guru membimbing peserta didik agar berlaku jujur, kreatif, bekerjasama dengan baik, dan menghargai antar-kelompok. Melalui kegiatan pembelajaran inilah, guru melatih peserta didik untuk bertanggung jawab, jujur serta taat.

\section{SIMPULAN}

Beberapa cara yang ditunjukkan Rasulullaah S.A.W. dalam memberikan pembelajaran dan dapat dijadikan sebagai pedoman dalam membentuk konsep pembelajaran, antara lain: (1) menggali apersepsi melalui tanya-jawab, yaitu mengumpulkan atau memanggil kembali ide-ide dan pengalaman peserta didik yang selanjutnya dijadikan dasar dalam menerima ide baru dari materi pelajaran; (2) mengajar dengan hikmah, pelajaran yang baik, dan membantah dengan cara yang baik. Hikmah adalah apabila seorang guru mengajar dengan tepat sasaran, membuat prioritas terhadap materi, megajar dengan memahami situasi, kondisi, dan kemampuan peserta didik, serta menyampaikan pembelajaran dengan bahasa yang mudah dipahami. Pelajaran yang baik mengandung nasihat dan nilai guna yang dapat diterapkan dikehidupan peserta didik. Sedangkan membantah dengan cara yang baik diartikan bahwa dalam meluruskan kesalahan yang terjadi pada peserta didik guru harus menyampaikannya dengan cara yang baik, tidak menjatuhkan mental peserta didik dan tidak membuat peserta didik merasa semakin susah dan menjauh; (3) Menggunakan media pembelajaran saat mengajar yang bertujuan membantu guru dalam memudahkan siswa memahami konsep yang diberikan guru. Beberapa media pembelajaran yang dipilih Rasulullaah S.A.W pada saat mengajarkan para sahabat adalah gambar, jari tangan, dan krikil; dan (4) mengaplikasikan materi dan nilai karakter dalam kehidupan, seperti bersikap jujur, adil, sistematis, saling menghargai, demokratis, taat, dan lain-lain yang juga telah Rasulullaah S.A.W. perlihatkan melalui sunnahnya. 


\section{REFERENSI}

Arbaa, R., Jamil, H., Razak, N.A. 2010. Hubungan Guru-Pelajar dan Kaitannya dengan Komitmen Belajar Pelajar: Adakah Guru Berkualiti Menghasilkan Perbezaan Pembelajaran antara Jantina Pelajar? (Jurnal Pendidikan Malaysia 35(2), dapat diakses pada http://journalarticle.ukm.my/1465/1/Bab_5.1.pdf)

Aslamiyah, S.S. 2013. Pendidik dalam Perspektif Pendidikan Islam (Jurnal Al Himab Vol. 3, No. 2, dapat diakses pada http://ejournal.kopertais4.or.id/pantura/index.php /alhikmah/ article/ download/371/220)

Baroroh, R.U. 2004. Beberapa Konsep Dasar Proses Belajar Mengajar Dalam Pembelajaran Pendidikan Agama Islam (Jurnal Pendidikan Agama Islam Vol. 1 No. 1, Mei-Oktober 2004, dapat diakses pada http://digilib.uin-suka.ac.id/8634/1 /R.\%20UMI\%20BAROROH \%20BEBERAPAKONSEP\%20DASAR\%20PROSES\%20BELAJAR\%20MENG AJAR\%20DAN\%20APLIKASINYA\%20DALAM\%20PEMBELAJARAN\%20P ENDIDIKAN\%20AGAMA\%20ISLAM.pdf).

Basrudin, Ratman, dan Gagaramusu, Y. 2013. Penerapan Metode Tanya Jawab untuk Meningkatkan Hasil Belajar Siswa pada Pokok Bahasan Sumber Daya Alam di Kelas IV SDN Fatufia Kecamatan Bahodopi (Jurnal Kreatif Tadulako Vol. 1, No. 1, dapat diakses pada http://jurnal.untad.ac.id/jurnal/index.php/JKTO/article/download/2979/2054).

Bilda, W. 2016. Pendidikan Karakter Terencana Melalui Pembelajaran (Jornal of Mathematics Education Vol. 2, No. 1, dapat diakses pada jurnalnasional.ump.ac.id/ index.php/alphamath / articleview/215/211).

Dahlan, M.S. 2014. Etika Komunikasi dalam Al-Qur'an dan Hadis (Jurnal Dakwah Tabligh Vol. 15, No. 1, dapat diakses pada http://journal.uin-alauddin.ac.id/index .php/tabligh/ article/download/342/313).

el-Qurtuby, Usman. 2012. Al-Qur'an Cordoba spesial for muslimah. Bandung: PT. Cordoba Internastional Indonesia

Elita, S. 2012. Efektivitas Metode Jarimatika dalam Meningkatkan Kemampuan Perkalian bagi Anak Kesulitan Belajar (Jurnal Ilmiah Pendidikan Khusus Vol. 1, No. 1, dapat diakses http://ejournal.unp.ac.id/index.php/jupekhu/article/viewFile/775/645).

Hussin, N., Rasul, M.S., Rauf, R.A. 2013. Penggunaan Laman Web Sebagai Transformasi dalam Pembelajaran dan Pembelajaran Pendidikan Islam (The Online Journal of Islamic Education Vol. 1 Issue 2, dapat dikses pada e-journal.um.edu.my/public/articleview.php?id=5557).

Idris, T dan Mahyuni, E. 2013. Upaya Guru dalam Mengatasi Kesulitan Belajar Al Quran Hadits di MIN Rukoh Darussalam Banda Aceh (Jurnal Pionir, Vol. 1, No. 1, dapat diakses pada jurnal.ar-raniry.ac.id/index.php/Pionir/article/view/152).

Maharani, H.R. 2014. Nilai-nilai Karakter dalam Pembelajaran Project Based Learning Materi Statistika SMP (Jurnal Pendidikan FKIP Unissula Vol. 2, No. 2, dapat diakses pada research.unissula.ac.id/file/.../9232Jurnal_hevy_PMAT_2014_Vol_2_No_2.pdf).

Marzuki. 2008. Meneladani Nabi Muhammad SAW. dalam Kehidupan Sehari-hari (Jurnal Humanika Vol. 8, No. 1, Maret 2008, blm. 75-87, dapat diakses pada http://eprints.uny.ac.id/2597/1/9._Meneladani_Nabi_Muhammad_Saw._dalam_ Kehidupan_Sehari-hari.pdf). 
Mohamed, S., Jasmi K.A., Zailani, M.A. 2016. Akhlak Guru dalam Pembelajaran dan Pembelajaran Pendidikan Islam (Jurnal Akdemika 86 (2), dapat diakses pada http://doi.org/10.17576/akad-2016-8602-0).

R., Mansur H. 2015. Menciptakan Pembelajaran Efektif Melalui Apersepsi (Artikel E-Buletin Edisi Februari, dapat diakses pada http://www.lpmpsulsel.net /v2/attachments/327 Menciptakan \%20pembelajaran\%20efektif\%20melalui\%20apersepsi.pdf).

Ramli, M. 2015. Media Pembelajaran dalam Perspektif Al-Qur'an dan Al-Hadits (Ittibad Jurnal Kopertais Wilayah XI Kalimantan Volume 13 No.23, dapat diakses pada idr.iainantasari.ac.id/4625/1/M\%20Ramli_Media\%20Pembelajaran.pdf).

Salafudin. 2011. Metode Pembelajaran Aktif Ala Rasulullah, Pembelajaran yang Membangkitkan Motivasi (Suatu Kajian Metode Pembelajaran dari Hadis) (Jurnal Forum Tarbiyah Vol. 9, No. 2, dapat diakses pada http://download.portalgaruda.org/ article.php?article $=251466 \& v a l=6753 \&$ title $=$ METODE $\% 20$ PEMBELAJARAN $\% 20$ AKTIF $\% 20 \mathrm{~A}$ LA \%20RASULULLAH, \%20PEMBELAJARAN\%20YANG\%20MEMBANGKI TKAN\%20MOTIVASI\%20(Suatu\%20Kajian\%20Metode\%20Pembelajaran\%20d ari $\% 20$ Hadis).

Salleh, S.A.M.B. dan Abdullah, W.N.B.W. 2014. Pengaplikasian Manhaj Rasulullah S.A.W. dalam Prose Pembelajaran dan Pembelajaran bagi Program Pengajian Tahfiz AlQur'an di Penjara Pengkalan Chepa Kelantan (Prosiding Seminar Pembelajaran \& Pembelajaran Bahasa Arab, dapat diakses pada https://seminarpnparab2014 .files.wordpress.com/2014/06/ siti-afifah-munirah-salleh.pdf).

Syarifuddin, A. 2011. Penerapan Model Pembelajaran Cooperative Belajar dan Faktor-Faktor yang Mempengaruhinya (Jurnal Ta'dib, Vol. XVI, No. 1, dapat diakses pada jurnal.radenfatah.ac.id/index.php/tadib/article/download/57/52). 